\title{
Application of otolith chemistry at multiple life history stages to assess population structure of Warsaw grouper in the Gulf of Mexico
}

\author{
P. J. Sanchez ${ }^{1, *}$, J. R. Rooker ${ }^{1}$, M. Zapp Sluis ${ }^{1}$, J. Pinsky ${ }^{1}$, M. A. Dance ${ }^{2}$, \\ B. Falterman ${ }^{3}$, R. J. Allman ${ }^{4}$ \\ ${ }^{1}$ Department of Marine Biology, Texas A\&M University (Galveston Campus), Galveston, TX 77554, USA \\ ${ }^{2}$ Department of Oceanography and Coastal Sciences, Louisiana State University, Baton Rouge, LA 70803, USA \\ ${ }^{3}$ Grand Isle Fisheries Research Lab, Louisiana Department of Wildlife and Fisheries, Baton Rouge, LA 70898, USA \\ ${ }^{4}$ Southeast Fisheries Science Center, National Marine Fisheries Service, Panama City, FL 32408, USA
}

\begin{abstract}
Chemical markers in otoliths have been used to assess the stock structure of many marine fishes, but these natural markers have yet to be widely evaluated or applied to demersal fishes in offshore habitats where physicochemical gradients are generally less pronounced relative to nearshore waters. To address this, we quantified trace elements ( $\mathrm{Li}, \mathrm{Mg}, \mathrm{Mn}, \mathrm{Co}, \mathrm{Cu}, \mathrm{Zn}$, $\mathrm{Sr}, \mathrm{Ba})$ and stable isotopes $\left(\delta^{13} \mathrm{C}\right.$ and $\left.\delta^{18} \mathrm{O}\right)$ in otoliths of Warsaw grouper Hyporthodus nigritus from 4 regions in the Gulf of Mexico (Texas, Louisiana, Alabama-NW Florida, and SW Florida). Region-specific differences in otolith chemistry were observed, and notable differences in several influential markers $\left(\mathrm{Mn}: \mathrm{Ca}, \mathrm{Sr}: \mathrm{Ca}\right.$, and $\mathrm{Ba}: \mathrm{Ca}$ ratios and $\delta^{18} \mathrm{O}$ ) were present, particularly between the most distant regions investigated (Texas/Louisiana and SW Florida). Distinct regional signatures were observed for Warsaw grouper across 3 life history stages: first year (otolith core), most recent years (otolith edge), and lifetime (whole otolith), suggesting that individuals within certain regions share common environmental histories that may represent unique contingents or subpopulations. Findings also demonstrate that spatial variability within these markers was consistent enough to overcome any temporal variability within the geographic domains investigated for all 3 life history stages, highlighting their potential value for assessing the natal origin, exchange, and population structure of this species and potentially other members of the deepwater fish assemblage.
\end{abstract}

KEY WORDS: Hyporthodus nigritus - Connectivity - Contingent - Metapopulation · Fisheries · Trace elements $\cdot$ Stable isotopes

\section{INTRODUCTION}

A variety of techniques are used to assess the movement and stock structure of marine fishes (see review by Cowen et al. 2007), including genetic markers (Ruzzante et al. 2000, Beltrán et al. 2017), conventional and electronic tagging (Merten et al. 2016, Rooker et al. 2019), and natural tracers in fish hard parts (e.g. otoliths, spines, vertebrae) (Rooker et al. 2010, Wells et al. 2010, Kitchens et al. 2018). Nat-

*Corresponding author: phillip.sanchez@tamu.edu ural tracers in otoliths (ear stones) are increasingly applied to retrospectively determine the origin and movement of fishes as the relationship between otolith chemistry and water chemistry becomes clearer and analytical precision improves (Tanner et al. 2016). This approach has been effectively utilized to determine the natal origin of an individual (Zapp Sluis et al. 2012, Rooker et al. 2014) and the timing of ontogenetic habitat shifts (Thorrold et al. 1998, Gillanders 2005, Elsdon et al. 2008) by targeting distinct

(1) The authors 2020. Open Access under Creative Commons by Attribution Licence. Use, distribution and reproduction are unrestricted. Authors and original publication must be credited. 
regions along the otolith growth axis. Moreover, quantifying chemical composition across the entire growth axis of the otolith (core to edge) serves as an integrated signature of all water masses occupied during the lifetime of an individual (Campana 1999, Thresher 1999), and therefore, has effectively been used to assess the connectivity, or lack thereof, of individuals from geographic regions with dissimilar water chemistries (Wells et al. 2015, Pita et al. 2016). While otolith chemistry has become a common tool for assessing the population connectivity of estuarine, nearshore, and oceanic fishes (Sturrock et al. 2012, Pita et al. 2016), comparable studies on species that occupy demersal habitats on the outer continental shelf or slope where physicochemical conditions of water masses are less pronounced are surprisingly limited (Elsdon et al. 2008), although a recent increase in studies around the Southern Ocean has proven the use of its application (Ashford et al. 2005, 2012, Zhu et al. 2018).

Warsaw grouper Hyporthodus nigritus (Epinephelidae) are a species of concern in the western Atlantic Ocean due to harvest pressure from recreational and commercial fisheries (Farmer \& Karnauskas 2013, Aguilar-Perera et al. 2018, Shertzer et al. 2018). These fish are periodic strategists within the Winemiller \& Rose (1992) trilateral continuum (high fecundity, late maturity, and long lived) that spawn in the spring and summer along the outer continental shelf (Smith 1971, Manooch \& Mason 1987, Parker \& Mays 1998, Sanchez et al. 2019). Therefore, Warsaw grouper are particularly susceptible to steady, long-term perturbations such as fishing exploitation, especially in agetruncated populations (Gerber \& Kendall 2016, Quetglas et al. 2016). Warsaw grouper are economically important in the Gulf of Mexico (GoM) as the third largest component of the commercial deepwater grouper fishery and are targeted trophy fish by recreational anglers (GMFMC 2018). As the second largest grouper species in the western Atlantic Ocean (>230 cm total length) and with an elevated trophic status (i.e. apex predator), Warsaw grouper exert topdown regulation and thus play an important ecological role in structuring deepwater communities (Shurin et al. 2002).

Throughout their range, Warsaw grouper are demersal and typically occur in deep, hard-bottom habitats below $50 \mathrm{~m}$ depth (Mejía-Ladino et al. 2003, Bender et al. 2013, Farmer \& Karnauskas 2013). The patchy and limited distribution of these habitats across the GoM likely restricts the movement of individuals, potentially causing geographic isolation and the development of sub-populations with different demographic traits (Koenig \& Coleman 2013). Nevertheless, Warsaw grouper in the GoM are currently managed as a single stock even though their population structure is presently unknown (Aguilar-Perera et al. 2018). This unknown status complicates their conservation because region- or sub-populationspecific demographics are required for the management of species displaying a metapopulation structure (Policansky \& Magnuson 1998, Begg et al. 1999). A single-stock management approach for marginally connected sub-populations can overestimate the population-wide maximum sustainable yield and therefore lead to unsustainable exploitation rates (Coleman et al. 2000, Longhurst 2002), highlighting the importance of an accurate population structure designation to develop effective conservation policy for threatened fish species (Thorrold et al. 2001).

Here, we applied natural chemical markers in otoliths of Warsaw grouper to investigate their population structure in the GoM, an important marginal sea in the center of their range. Two classes of chemical markers - trace elements ( $\mathrm{Li}, \mathrm{Mg}, \mathrm{Mn}, \mathrm{Co}, \mathrm{Cu}, \mathrm{Zn}$, $\mathrm{Sr}, \mathrm{Ba})$ and stable isotopes $\left(\delta^{18} \mathrm{O}\right.$ and $\left.\delta^{13} \mathrm{C}\right)$ - were quantified from 4 regions of the GoM (Texas, Louisiana, Alabama-NW Florida, and SW Florida), and region-specific signatures were evaluated at 3 different life history stages of the otolith to assess early life, most recent growth, and lifetime variability in these markers. We predicted that limited movement of Warsaw grouper among regions and/or the presence of sub-populations with unique environmental histories would result in strong region-specific trends in otolith chemistry at all life history stages.

\section{MATERIALS AND METHODS}

\subsection{Sample collection and age determination}

Archived otoliths from Warsaw grouper were acquired from the National Oceanic and Atmospheric Administration (NOAA) Fisheries' Southeast Regional Office in Panama City, Florida. Otoliths were collected by NOAA commercial fishery observers on benthic longline and handline fishing vessels. Analyzed specimens were restricted to a maximum total length (TL) of $100 \mathrm{~cm}$ and collection years 2011-2015 to minimize the confounding effects of ontogenetic and temporal variability on elemental composition of otoliths. Every available archived otolith that fit these criteria was selected and processed for this study. While depth data were not available for most gear sets, depth of set for the GoM 
deepwater grouper fishery typically ranges between 100 and $300 \mathrm{~m}$. Samples were grouped into 4 regions determined by the reported commercial GoM shrimp zone catch location: Southeast (SE: Zones 1-5; Florida Keys to Tampa Bay, Florida), Northeast (NE: Zones 6-10; Tampa Bay, Florida, to Mobile Bay, Alabama), Northcentral (NC: Zones 11-16; Mobile Bay, Alabama, to central Louisiana), and Northwest (NW: Zones 17-21; western Louisiana and Texas) (Fig. 1). Our regional sampling design was based on expected differences in ambient water chemistry resulting from the geographic positions of Mississippi and Atchafalaya River System inflow and the Loop Current in the GoM.

Otoliths were cleaned of biological material with Teflon-coated forceps and double-deionized water (DDIH $\mathrm{O}_{2}$; ultrapure, $18 \mathrm{M} \Omega \mathrm{cm}^{-1}$ water), allowed to air dry, weighed to the nearest $0.1 \mathrm{mg}$, and embedded in Struers epoxy resin following Rooker et al. (2008). Embedded otoliths were then sectioned along the transverse plane at $1.5 \mathrm{~mm}$ thickness using a Buehler ISOMET saw to expose the primordium and growth increments. Otolith thin sections were mounted onto petrographic slides with Crystalbond 509 thermoplastic glue and polished on one side until the center of the primordium was visible while attempting not to reduce thickness below $1 \mathrm{~mm}$. Two independent readers determined fish ages by counting annual growth increments on the otolith micro- structure, a method previously validated for Warsaw grouper (Sanchez et al. 2019).

\subsection{Trace elements}

Trace element composition of Warsaw grouper otoliths was assessed using an ultraviolet New Wave Research laser ablation (LA) system (NWR213) coupled with a quadrupole Thermo Scientific XSeries 2 inductively coupled plasma mass spectrometer (ICP-MS) located at Texas A\&M University (Galveston Campus). Multiple otolith thin sections were mounted onto single petrographic slides, with slides presented randomly to the machine. A series of $70 \mu \mathrm{m}$ diameter spots from the core to the margin were ablated on each otolith, with a spacing of $150 \mu \mathrm{m}$ between centroids of successive spots (ca. $80 \mu \mathrm{m}$ non-quantified area between edges of consecutive ablation spots). Organization of ablation spots targeted 3 distinct regions of the otolith thin section: (1) core (young-of-the year [YOY] period), (2) edge (recent growth period), and (3) lifetime (complete growth axis from core to edge) (Fig. 2A). The core consisted of 5 spots arranged in an M-shape contained within the opaque primordium with a central point at the base of sulcal groove. Two points, one on each side, followed the respective dorsal and ventral grooves up $150 \mu \mathrm{m}$, while 2 additional points

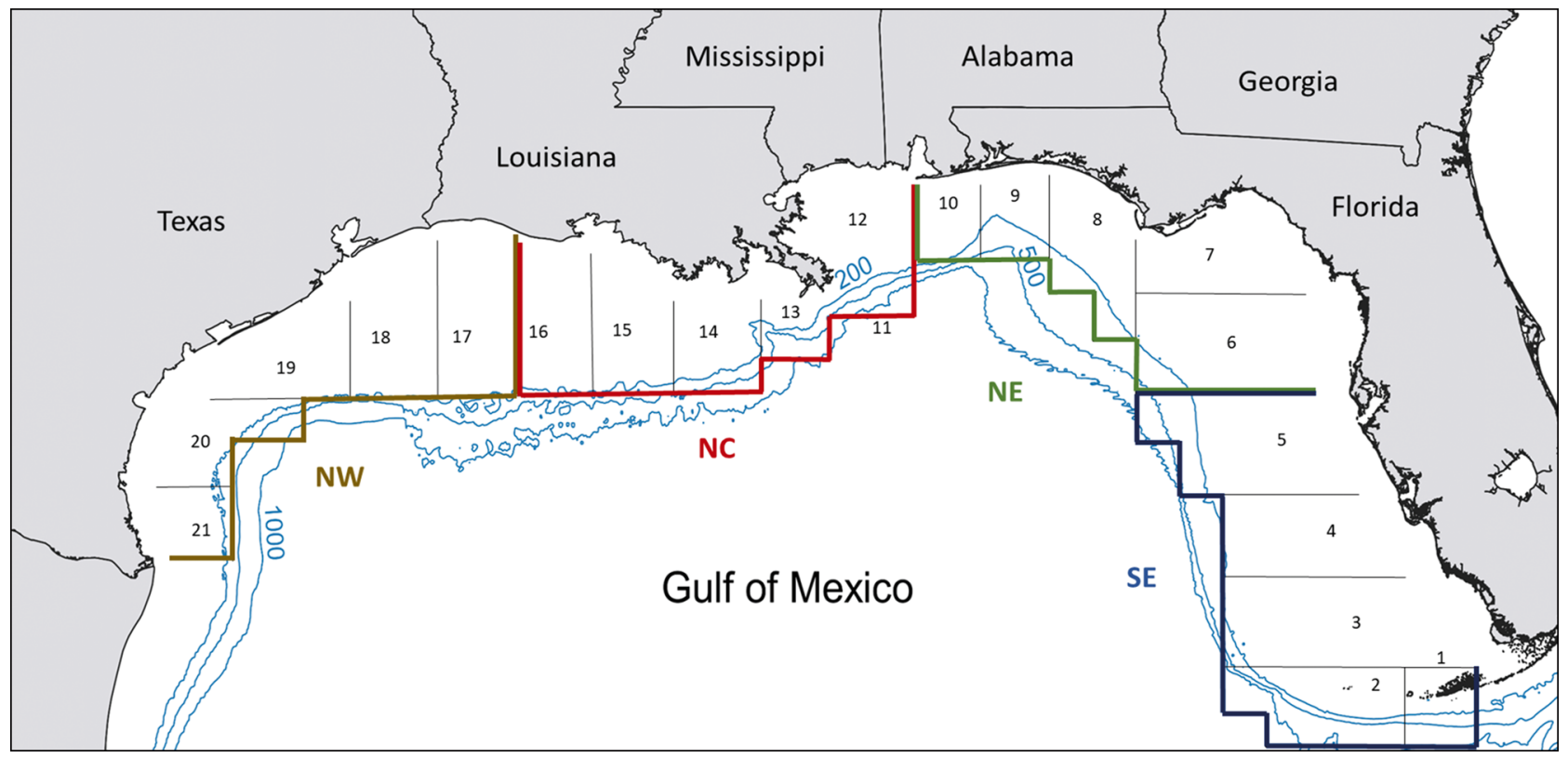

Fig. 1. Gulf of Mexico commercial shrimp zones with the 4-region groups labeled; SE (Southeast, Zones 1-5), NE (Northeast, 6-10), NC (Northcentral, 11-16), NW (Northwest, 17-19). No samples were collected in shrimp Zones 1, 11, 12, 20, or 21. The 200, 500, and $1000 \mathrm{~m}$ depth contours are shown in blue 


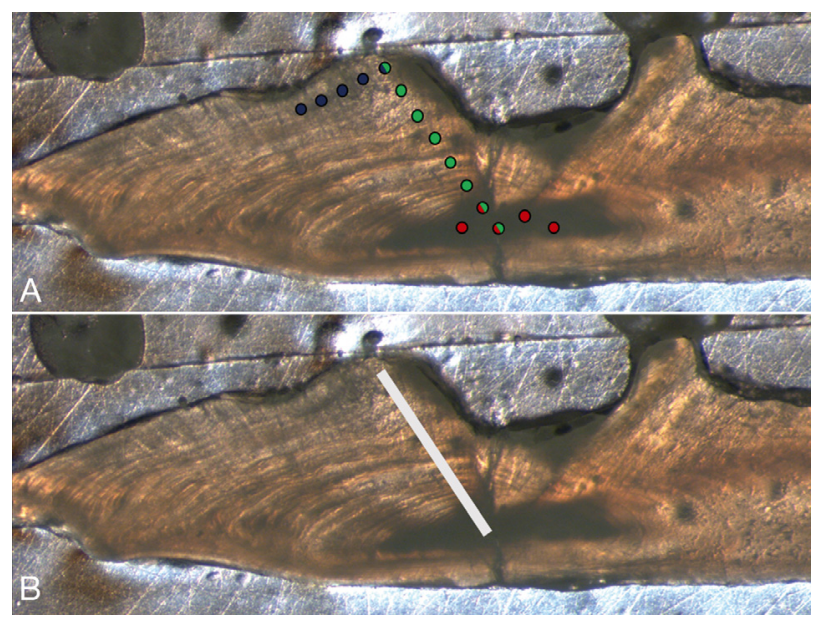

Fig. 2. Example of (A) trace element sample groupings and (B) stable isotope sample transect on the Warsaw grouper otolith thin section. Red circles: core (first year) ablation points; green circles: lifetime transect ablation points; black circles: edge (recent growth period) ablation points. Points with 2 designations (half/half) were ablated once but included in both corresponding signatures. The stable isotopes transect was milled with a $300 \mu \mathrm{m}$ drill bit, and all material was pooled into a single powdered sample per otolith

were placed approximately $150 \mu \mathrm{m}$ lateral (along the fast growth axis) of the central point. Lifetime samples included all points along the growth axis from the core to the edge of the otolith on the dorsal side of the sulcal groove. Edge samples (i.e. recently accreted material) consisted of 5 points positioned laterally along the distal edge of the otolith.

National Institute of Standards and Technology (NIST) 612 carbonate standards, with ablation settings identical to the otolith samples, were analyzed to calibrate trace element concentrations from counts per second. To assess potential drift within the ICPMS, 1 NIST 612 standard was ablated after the $10^{\text {th }}$ sample ablation spot for each individual otolith, and a cycle of 1 MACS and 1 NIST 612 standard was run after each otolith. All regions of otoliths and carbonate standards assayed were first pre-ablated at $60 \%$ laser output and $10 \mathrm{~Hz}$ intensity for a $1 \mathrm{~s}$ dwell time to remove any potential contamination from the surface of the otolith. Spots were then ablated for trace element analysis at $50 \%$ laser output, $10 \mathrm{~Hz}$ intensity, 30 s laser warmup (blank run), and $30 \mathrm{~s}$ dwell time (sample run). Trace element concentrations in parts per billion (ppb) were measured for ${ }^{7}$ Lithium (Li), ${ }^{24}$ Magnesium (Mg), ${ }^{43}$ Calcium (Ca), ${ }^{55}$ Manganese $(\mathrm{Mn}),{ }^{59}$ Cobalt $(\mathrm{Co}),{ }^{65} \mathrm{Copper}(\mathrm{Cu}),{ }^{66} \mathrm{Zinc}(\mathrm{Zn})$, ${ }^{88}$ Strontium (Sr), and ${ }^{137}$ Barium (Ba). Concentrations were then converted to element:Ca $\left(\mu \mathrm{mol} \mathrm{mmol}^{-1}\right)$ ratios using the formula:

$$
\left.\mathrm{X}: \mathrm{Ca}=\left(\mathrm{ppb}_{\mathrm{X}} \times 0.001\right) / Z_{\mathrm{X}}\right) /(0.38 / 43)
$$

where $\mathrm{X}$ is the element analyzed, $\mathrm{ppb}_{\mathrm{X}}$ its measured concentration, $Z_{\mathrm{X}}$ its atomic mass, and the denominator $(0.38 / 43)$ is the standard parts per million concentration (0.38) and atomic mass (43) of ${ }^{43}$ Calcium in aragonitic calcium carbonate.

\subsection{Stable isotopes}

A subset of the otoliths analyzed for trace elements was selected for $\delta^{18} \mathrm{O}$ and $\delta^{13} \mathrm{C}$ analysis. To develop a more balanced sample design for evaluating both classes of chemical markers, selection included all otoliths from the SE $(n=19), \operatorname{NE}(n=10)$, and NW $(n=$ 15) regions not removed in the post-processing of lifetime results, and 19 randomly selected otoliths from the NC. Selected otolith thin sections from LA-ICPMS runs were lightly polished until ablation spots were no longer visible, removing the upper layer of material where trace element analysis was conducted. A precision micromill (New Wave Research MicroMill) was used to collect otolith material along a transect running from the core to the distal edge along the growth axis (Fig. 2B). The transect line was ca. $300 \mu \mathrm{m}$ wide, and 14 passes at $55 \mu \mathrm{m}$ depth were performed resulting in a sample depth of $770 \mu \mathrm{m}$. We assumed that otolith powder collected from the transect line for $\delta^{18} \mathrm{O}$ and $\delta^{13} \mathrm{C}$ analysis corresponded to the lifetime sample described above for trace elements. Otolith $\delta^{18} \mathrm{O}$ and $\delta^{13} \mathrm{C}$ analysis was performed at the University of Arizona using an automated carbonate preparation device (KIEL-III; Thermo Fisher Scientific) coupled to a Thermo Fisher Scientific MAT 252 isotope ratio mass spectrometer. Powdered otolith samples were reacted with dehydrated phosphoric acid under vacuum at $70^{\circ} \mathrm{C}$. The isotope ratio measurement was calibrated based on repeated measurements of National Bureau of Standards (NBS), NBS19 and NBS-18, with 6 standards run for every 40 samples; precision was $\pm 0.08 \%$ o (SD) and $\pm 0.11 \%$ for $\delta^{18} \mathrm{O}$ and $\delta^{13} \mathrm{C}$, respectively. Otolith $\delta^{18} \mathrm{O}$ and $\delta^{13} \mathrm{C}$ values are reported relative to the Vienna Pee Dee Belemnite (VPDB) scale after comparison to an inhouse laboratory standard calibrated to VPDB.

\subsection{Data analysis}

Before analysis, data were post-processed to remove outliers. Element:Ca values were pooled by region, and all samples with values $\pm 5 \mathrm{SD}$ of the 
mean for each individual marker were considered outliers and removed from any subsequent analysis. Post-processing was conducted for each life history stage independently and therefore resulted in different sample sizes for each due to differences in the number of otoliths considered outliers and removed.

Multivariate analysis of variance (MANOVA) and ANOVA were used to determine whether chemical signatures (multiple markers) or individual markers, respectively, differed among geographic regions, with year incorporated as an interactive factor $(\alpha=$ 0.05) (RStudio, package 'nlme'). Tukey's highly significant difference (HSD) tests with a 'Shaffer' corrected alpha $(\alpha=0.05)$ were run on interaction models (Region $\times$ Year) to analyze region-specific differences for individual markers with significant ANOVA results. Quadratic discriminant function analysis (QDFA) was used to assess regional classification of Warsaw grouper based on trace element signatures from the otolith core and edge using a standard set of elements identified as influential ( $\alpha=$ 0.10) from ANOVA tests (SYSTAT 13). Jackknifed cross-validated classification success was determined for models with 4-region and 2-region groupings with prior probabilities based on region-specific sample size to account for unbalanced sample sizes

Table 1. Sample size (n), mean age, and mean total length (TL), of all Warsaw grouper in the study (Total) and by Gulf of Mexico region. NW: northwest; NC: north central; SE: southeast; NE: northeast; APE: average percent error

\begin{tabular}{|lcccccc|}
\hline Region & $\mathrm{n}$ & $\begin{array}{c}\text { Mean } \\
\text { age (yr) }\end{array}$ & $\begin{array}{c}\text { SD age } \\
(\mathrm{yr})\end{array}$ & $\begin{array}{c}\text { APE } \\
(\%)\end{array}$ & $\begin{array}{c}\text { Mean TL } \\
(\mathrm{mm})\end{array}$ & $\begin{array}{c}\text { SD } \\
\mathrm{TL}\end{array}$ \\
\hline Total & 129 & 4.4 & 1.2 & 6.9 & 810 & 68 \\
NW & 18 & 4.9 & 1.6 & 7.6 & 836 & 69 \\
NC & 79 & 4.5 & 1.2 & 5.4 & 820 & 67 \\
SE & 22 & 3.8 & 0.7 & 5.4 & 777 & 53 \\
NE & 10 & 3.6 & 0.4 & 7.6 & 783 & 55 \\
\hline
\end{tabular}

across regions. The 2-region grouping was created by combining the NW, NC, and NE GoM regions due their close proximity to the Mississippi River inflow. MANOVA and ANOVA again were used to assess regional differences in chemical signatures (trace elements and stable isotopes) and individual markers. For lifetime signatures, classification success (QDFA) was determined using models based on combined marker classes (both trace elements and stable isotopes) and individual marker classes (trace elements only or stable isotopes only) to determine the value of each for classifying Warsaw grouper to the different geographic regions.

\section{RESULTS}

Otoliths from 129 Warsaw grouper from the NOAA Fisheries' archives that fit selection criteria were available for geochemical analysis. For all samples, TL was $810 \pm 40 \mathrm{~mm}$ (mean $\pm \mathrm{SD}$ ), and the mean determined age was $4.4 \pm 1.2 \mathrm{yr}$ with an average percent error of $7.0 \%(0.6 \mathrm{yr})$ between 2 readers (Table 1). Five elements ( $\mathrm{Li}, \mathrm{Mg}, \mathrm{Mn}, \mathrm{Sr}$, and $\mathrm{Ba}$ ) in the otoliths were consistently above detection limits and were used for statistical testing; $\mathrm{Co}, \mathrm{Cu}$, and $\mathrm{Zn}$ were often below detection limits and removed from further analyses. After data post-processing, 3 and 8 otoliths were removed from the core $(n=126)$ and edge $(n=121)$ analyses, respectively.

Chemical signatures in the otolith ${ }_{\text {core }}$ (YOY period) of Warsaw grouper varied significantly among the 4 regions (MANOVA, p < 0.001) (Table 2). Univariate contrasts indicated that otolith ${ }_{\text {core }} \mathrm{Mn}: \mathrm{Ca}, \mathrm{Sr}: \mathrm{Ca}$, and $\mathrm{Ba}$ :Ca ratios were significantly different (ANOVA, p $<0.05)$ between GoM regions. Otolith ${ }_{\text {core }} \mathrm{Mn}: \mathrm{Ca}$, $\mathrm{Sr}: \mathrm{Ca}$, and $\mathrm{Ba} \mathrm{Ca}$ values were higher in the $\mathrm{NC}$ region $(\mathrm{Mn}: \mathrm{Ca}=3.09 \pm 1.32 ; \mathrm{Sr}: \mathrm{Ca}=2715 \pm 304 ;$ $\mathrm{Ba}: \mathrm{Ca}=5.03 \pm 2.04)$ than the $\mathrm{SE}$ region $(\mathrm{Mn}: \mathrm{Ca}=$

Table 2. Multivariate analysis of variance (MANOVA) degrees of freedom (numerator, denominator), $F$-values, and p-values (Pillai's trace) of 4-region (Northwest [NW], Northcentral [NC], Northeast [NE], and Southeast [SE]) and 2-region (NW/NC/NE and SE) groupings of Warsaw grouper otoliths in the Gulf of Mexico. The only interactive effect between Region and Year was for edge (recent growth period) samples in the 4-region analysis

\begin{tabular}{|c|c|c|c|c|c|c|c|c|c|c|}
\hline & \multirow{2}{*}{$\begin{array}{l}\text { Otolith } \\
\text { sample }\end{array}$} & \multirow[b]{2}{*}{$\mathrm{df}$} & \multirow{2}{*}{$\begin{array}{c}\text { Region } \\
F\end{array}$} & \multirow[b]{2}{*}{$\mathrm{p}$} & \multirow[b]{2}{*}{ df } & \multirow{2}{*}{$\begin{array}{c}\text { Year } \\
F\end{array}$} & \multirow[b]{2}{*}{$\mathrm{p}$} & \multicolumn{3}{|c|}{$\longrightarrow$ Region $\times$ Year } \\
\hline & & & & & & & & $\mathrm{df}$ & $F$ & $\mathrm{p}$ \\
\hline \multirow[t]{3}{*}{ 4-Region } & Core & 15,321 & 4.5 & $<0.001$ & 20,432 & 2.7 & $<0.001$ & 55,545 & 1.0 & $>0.05$ \\
\hline & Edge & 15,306 & 3.4 & $<0.001$ & 20,412 & 2.3 & $<0.01$ & 55,520 & 1.6 & $<0.01$ \\
\hline & Lifetime & 21,153 & 3.1 & $<0.001$ & 7,49 & 2.9 & $<0.05$ & 21,153 & 1.2 & $>0.05$ \\
\hline \multirow[t]{3}{*}{ 2-Region } & Core & 5,114 & 10.8 & $<0.001$ & 20,468 & 2.8 & $<0.001$ & 20,468 & 0.78 & $>0.05$ \\
\hline & Edge & 5,109 & 6.1 & $<0.001$ & 20,448 & 2.4 & $<0.01$ & 20,448 & 0.95 & $>0.05$ \\
\hline & Lifetime & 7,53 & 8.9 & $<0.001$ & 7,53 & 3.4 & $<0.01$ & 7,53 & 1.5 & $>0.05$ \\
\hline
\end{tabular}


$1.12 \pm 0.38 ; \mathrm{Sr}: \mathrm{Ca}=2527 \pm 274 ; \mathrm{Ba}: \mathrm{Ca}=3.45 \pm 1.94)$ (Fig. 3A-C). Otolith ${ }_{\text {core }}$ element:Ca ratios for individuals from the NW (Mn:Ca $=2.55 \pm 0.91 ; \mathrm{Sr}: \mathrm{Ca}=$ $2451 \pm 271 ; \mathrm{Ba}: \mathrm{Ca}=4.19 \pm 2.09)$ and $\mathrm{NE}$ regions $(\mathrm{Mn}: \mathrm{Ca}=2.26 \pm 1.03 ; \mathrm{Sr}: \mathrm{Ca}=2579 \pm 390 ; \mathrm{Ba}: \mathrm{Ca}=$ $5.07 \pm 3.60)$ were intermediate between the $\mathrm{NC}$ and SE, with the exception of Sr:Ca in the NW (Table A1 in the Appendix). No regional differences in otolith cores were observed for otolith core $_{\mathrm{Mg}} \mathrm{Ca}$ or $\mathrm{Li}: \mathrm{Ca}$ ratios (ANOVA, p > 0.05). Overall jackknifed classification success from QDFA to the 4 regions using otolith $_{\text {core }}$ element ratios (Mg:Ca, $\mathrm{Mn}: \mathrm{Ca}, \mathrm{Sr}: \mathrm{Ca}$, and $\mathrm{Ba}$ :Ca) was $72 \%$, with a high level of variation in classification success among regions: NW (25\%), NC $(92 \%)$, NE (0\%), and SE (67\%). The 2-region grouping resulted in significant differences between regions and among years (MANOVA, p < 0.05) with no interaction, and increased overall jackknifed classification success to $94 \%$ (Table 3, Fig. 4A).

Chemical signatures in the otolith edge $_{\text {of Warsaw }}$ grouper (most recent period) also varied significantly
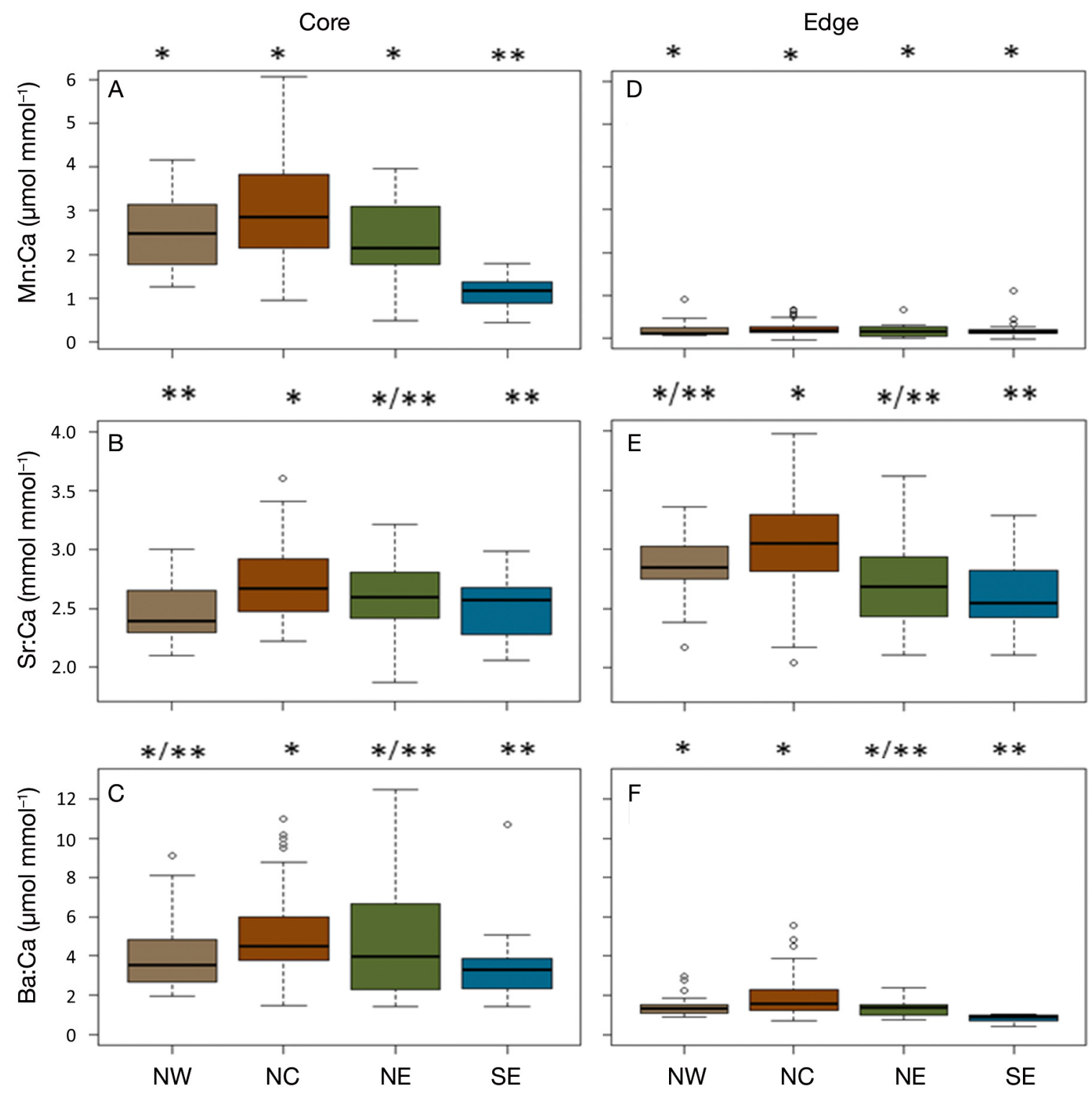

Fig. 3. (A,D) Mn:Ca, $(B, E) \mathrm{Sr}: \mathrm{Ca}$, and $(\mathrm{C}, \mathrm{F}) \mathrm{Ba}$ :Ca ratios for core $(\mathrm{A}-\mathrm{C})$ and edge $(\mathrm{D}-\mathrm{F})$ values based on the Gulf of Mexico 4 -region grouping for all Warsaw grouper otolith samples in the study $(\mathrm{n}=126)$. Asterisks denote Tukey HSD groupings $(\alpha=$ 0.05) for the univariate (ANOVA) tests. Box range represents the IQR of the data with the mean indicated by the black line, circles are outliers. NW: Northwest; NC: Northcentral; NE: Northeast; SE: Southeast 
among the 4 regions (MANOVA, $\mathrm{p}<0.001$ ) (Table 2). Univariate contrasts indicated that otolith edge $_{\mathrm{Sr}} \mathrm{Ca}$ and Ba:Ca were different (ANOVA, p < 0.05) between regions. Otolith ${ }_{\text {edge }} \mathrm{Sr}: \mathrm{Ca}$ and $\mathrm{Ba}: \mathrm{Ca}$ were higher in the NC region $(\mathrm{Sr}: \mathrm{Ca}=3045 \pm 373 ; \mathrm{Ba}: \mathrm{Ca}=1.89 \pm$ 0.95 ) than the $\mathrm{SE}$ region $(\mathrm{Sr}: \mathrm{Ca}=2637 \pm 345$; $\mathrm{Ba}: \mathrm{Ca}=$
Table 3. Jackknifed classification success (\%) from quadratic discriminant function analysis (QDFA) for 4-region and 2-region groupings for Warsaw grouper otolith core (first year) and edge (recent growth period) samples using trace elements only $(\mathrm{Mg}, \mathrm{Mn}, \mathrm{Sr}, \mathrm{Ba})$, and lifetime samples using trace elements and $\delta^{18} \mathrm{O}$ with sample sizes (n) per region. NW: Northwest; NC: Northcentral; NE: Northeast; SE: Southeast

\begin{tabular}{|ccccccccccc|}
\hline & $\mathrm{n}$ & Region & NW & NC & NE & SE & $\%$ & n & 2-Region & $\%$ \\
\hline Core & 16 & NW & 4 & 9 & 1 & 2 & 25 & 105 & NW/NC/NE & 98 \\
& 79 & NC & 5 & 73 & 1 & 0 & 92 & 21 & SE & 76 \\
& 10 & NE & 0 & 7 & 1 & 2 & 0 & & Overall & $\mathbf{9 4}$ \\
& 21 & SE & 1 & 4 & 2 & 14 & 67 & & & \\
Edge & 18 & Overall & & & & & $\mathbf{7 2}$ & & & \\
& 76 & NC & 2 & 11 & 1 & 4 & 11 & 104 & NW/NC/NE & 90 \\
& 10 & NE & 1 & 4 & 2 & 3 & 20 & & Overall & $\mathbf{8 8}$ \\
& 17 & SE & 0 & 5 & 0 & 12 & 71 & & & \\
Life- & 15 & Overall & & & & & $\mathbf{6 7}$ & & & \\
time & 19 & NC & 3 & 5 & 1 & 4 & 33 & 44 & NW/NC/NE & 89 \\
& 10 & NE & 3 & 2 & 3 & 2 & 30 & & Overall & $\mathbf{8 4}$ \\
& 19 & SE & 3 & 0 & 0 & 16 & 84 & & & \\
& & Overall & & & & & $\mathbf{6 0}$ & & & \\
\hline
\end{tabular}

$0.85 \pm 0.18$ ) (Fig. 3E,F). Otolith $\mathrm{Sr}: \mathrm{Ca}$ and $\mathrm{Ba}: \mathrm{Ca}$ ratios for individuals from the NW (Sr:Ca = $2944 \pm 538$; $\mathrm{Ba}: \mathrm{Ca}=1.49 \pm 0.61)$ and $\mathrm{NE}(\mathrm{Sr}: \mathrm{Ca}=$ $2731 \pm 409 ; \mathrm{Ba}: \mathrm{Ca}=1.36 \pm 0.48$ ) regions were intermediate between the $\mathrm{NC}$ and SE. No regional differences were

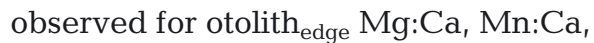
or Li:Ca values (ANOVA, p > 0.05). Overall jackknifed classification success from QDFA to the 4 regions using otolith $_{\text {edge }}$ element ratios (Mg:Ca, $\mathrm{Mn}: \mathrm{Ca}, \mathrm{Sr}: \mathrm{Ca}$, and $\mathrm{Ba}: \mathrm{Ca})$ was $67 \%$, with a high level of variation in classification success among regions: NW $(11 \%), \mathrm{NC}(86 \%), \mathrm{NE}(20 \%)$, and SE (71\%). The 2-region grouping resulted in significant differences between regions and among years (MANOVA, p < 0.05 ) with no interaction, and increased overall jackknifed classification success to $88 \%$ (Table 3, Fig. 4B).
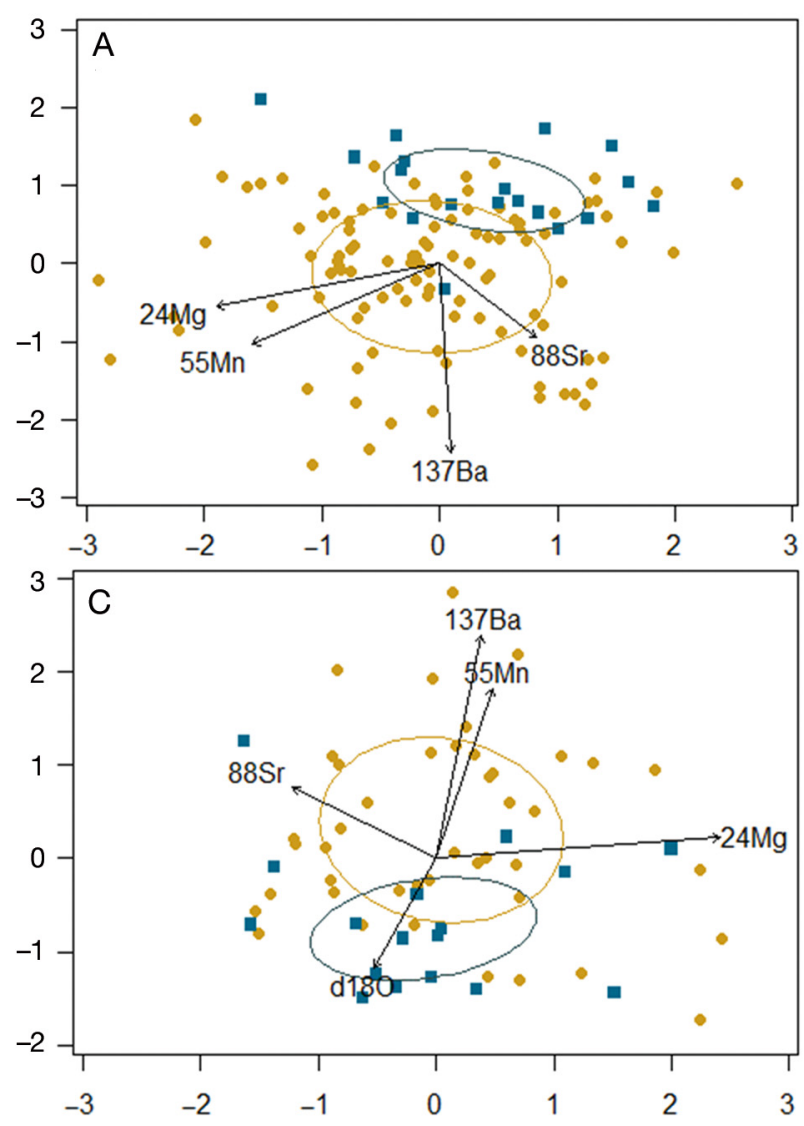

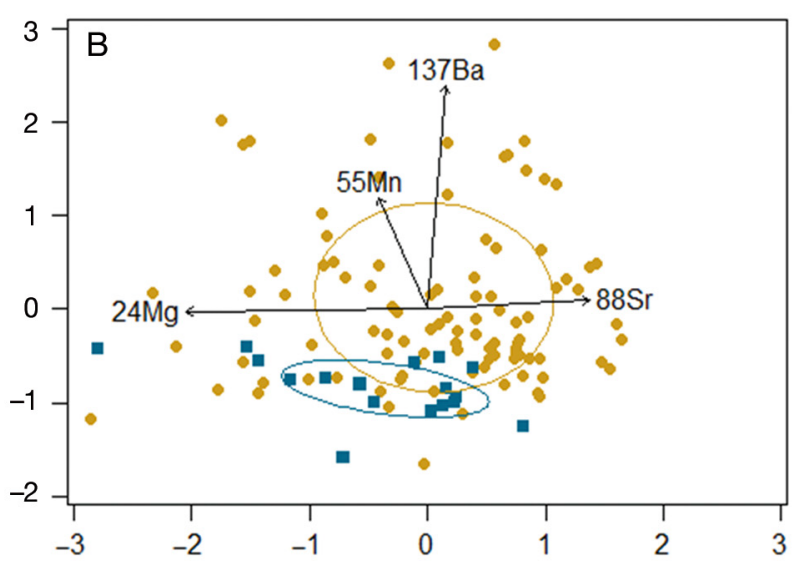

Fig. 4. Canonical correspondence plots of chemical signatures with overlaid 2-region ordination ellipses for (A) core samples and (B) edge samples of trace elements only ( $\mathrm{Mg}$, $\mathrm{Mn}, \mathrm{Sr}, \mathrm{Ba})$, and (C) lifetime samples with trace elements and $\delta^{18} \mathrm{O}$. Vector influence of each analytical parameter overlaid on CCA plots. North: Northwest, Northcentral, and Northeast regions (yellow), South: Southeast region (blue) 
Otolith $_{\text {lifetime }}$ signatures using combined marker classes (trace elements and stable isotopes) varied significantly among the 4 regions (MANOVA, $\mathrm{p}<0.001$ ) (Table 2). Univariate contrasts indicated that otolith life- $_{\text {- }}$ time $\mathrm{Mn}: \mathrm{Ca}, \mathrm{Sr}: \mathrm{Ca}, \mathrm{Ba}: \mathrm{Ca}$, and $\delta^{18} \mathrm{O}$ were different (ANOVA, p < 0.05) between regions. Otolith lifetime $_{\text {. }}$ $\mathrm{Mn}: \mathrm{Ca}, \mathrm{Sr}: \mathrm{Ca}$, and $\mathrm{Ba}: \mathrm{Ca}$ ratios were higher in the $\mathrm{NC}$ region $(\mathrm{Mn}: \mathrm{Ca}=1.20 \pm 0.38 ; \mathrm{Sr}: \mathrm{Ca}=2692 \pm 210$; $\mathrm{Ba}: \mathrm{Ca}=3.53 \pm 0.97)$ than the $\mathrm{SE}$ region $(\mathrm{Mn}: \mathrm{Ca}=0.46$ $\pm 0.35 ; \mathrm{Sr}: \mathrm{Ca}=2467 \pm 200 ; \mathrm{Ba}: \mathrm{Ca}=1.93 \pm 0.72$ ) (Fig. $5 \mathrm{~A}-\mathrm{C})$. Otolith lifetime $_{\text {element:Ca ratios for individuals }}$ from the NW (Mn:Ca $=0.92 \pm 0.52 ; \mathrm{Sr}: \mathrm{Ca}=2618 \pm 166$; $\mathrm{Ba}: \mathrm{Ca}=2.45 \pm 0.86)$ and $\mathrm{NE}(\mathrm{Mn}: \mathrm{Ca}=0.68 \pm 0.36$; $\mathrm{Sr}: \mathrm{Ca}=2570 \pm 189 ; \mathrm{Ba}: \mathrm{Ca}=2.74 \pm 1.18$ ) regions were intermediate between the $\mathrm{NC}$ and $\mathrm{SE}$. Otolith lifetime $_{\text {. }}$ $\delta^{18} \mathrm{O}$ values were higher in the SE $(-0.01 \pm 0.29)$ than all other regions $(\mathrm{NW}=-0.29 \pm 0.27 ; \mathrm{NC}=-0.41 \pm$ $0.16 ; \mathrm{NE}=-0.39 \pm 0.21$ ) (Fig. 5D). No regional differences were observed for $\mathrm{Mg}: \mathrm{Ca}, \mathrm{Li}: \mathrm{Ca}$, or $\delta^{13} \mathrm{C}$ (ANOVA, $\mathrm{p}>0.05$ ). Overall classification success from QDFA using a combination of markers $(\mathrm{Mg}: \mathrm{Ca}$, $\mathrm{Mn}: \mathrm{Ca}, \mathrm{Sr}: \mathrm{Ca}, \mathrm{Ba}: \mathrm{Ca}$, and $\delta^{18} \mathrm{O}$ ) to the 4-region grouping using otolith ${ }_{\text {lifetime }}$ signatures was $60 \%$, with a high level of variation in classification success among regions: NW (33\%), NC (74\%), NE (30\%), SE (84\%).
The 2-region grouping resulted in significant differences between regions and among years (MANOVA, $\mathrm{p}<0.05)$ with no interaction, and increased overall jackknifed classification success to $84 \%$ (Table 3, Fig. 4C). Total classification success for the 2-region grouping (NC/NW/NE and SE) remained relatively consistent whether using trace elements only $(83 \%)$, stable isotopes $\left(\delta^{18} \mathrm{O}\right.$ and $\left.\delta^{13} \mathrm{C}\right)$ only $(84 \%)$, or a combination of trace elements and $\delta^{18} \mathrm{O}(84 \%)$ (Table 4$)$.

Table 4. Jackknifed classification success (\%) from quadratic discriminant function analysis (QDFA) for 2-region grouping of the stable isotope sample subset lifetime signature from Warsaw grouper otoliths using trace elements only $(\mathrm{Mg}, \mathrm{Mn}, \mathrm{Sr}, \mathrm{Ba})$, stable isotopes only $\left(\delta^{18} \mathrm{O}\right.$ and $\left.\delta^{13} \mathrm{C}\right)$, and trace elements and $\delta^{18} \mathrm{O}$. NW: Northwest; NC: Northcentral; NE: Northeast; SE: Southeast

\begin{tabular}{|lcccc|}
\hline Region & $\mathrm{n}$ & $\begin{array}{c}\text { Trace } \\
\text { elements } \\
\text { only }\end{array}$ & $\begin{array}{c}\delta^{18} \mathrm{O} \text { and } \\
\delta^{13} \mathrm{C} \\
\text { only }\end{array}$ & $\begin{array}{c}\text { Trace } \\
\text { elements } \\
\text { with } \delta^{18} \mathrm{O}\end{array}$ \\
\hline NW/NC/NE & 44 & 89 & 95 & 89 \\
SE & 19 & 68 & 58 & 74 \\
Overall & & 83 & 84 & 84 \\
\hline
\end{tabular}
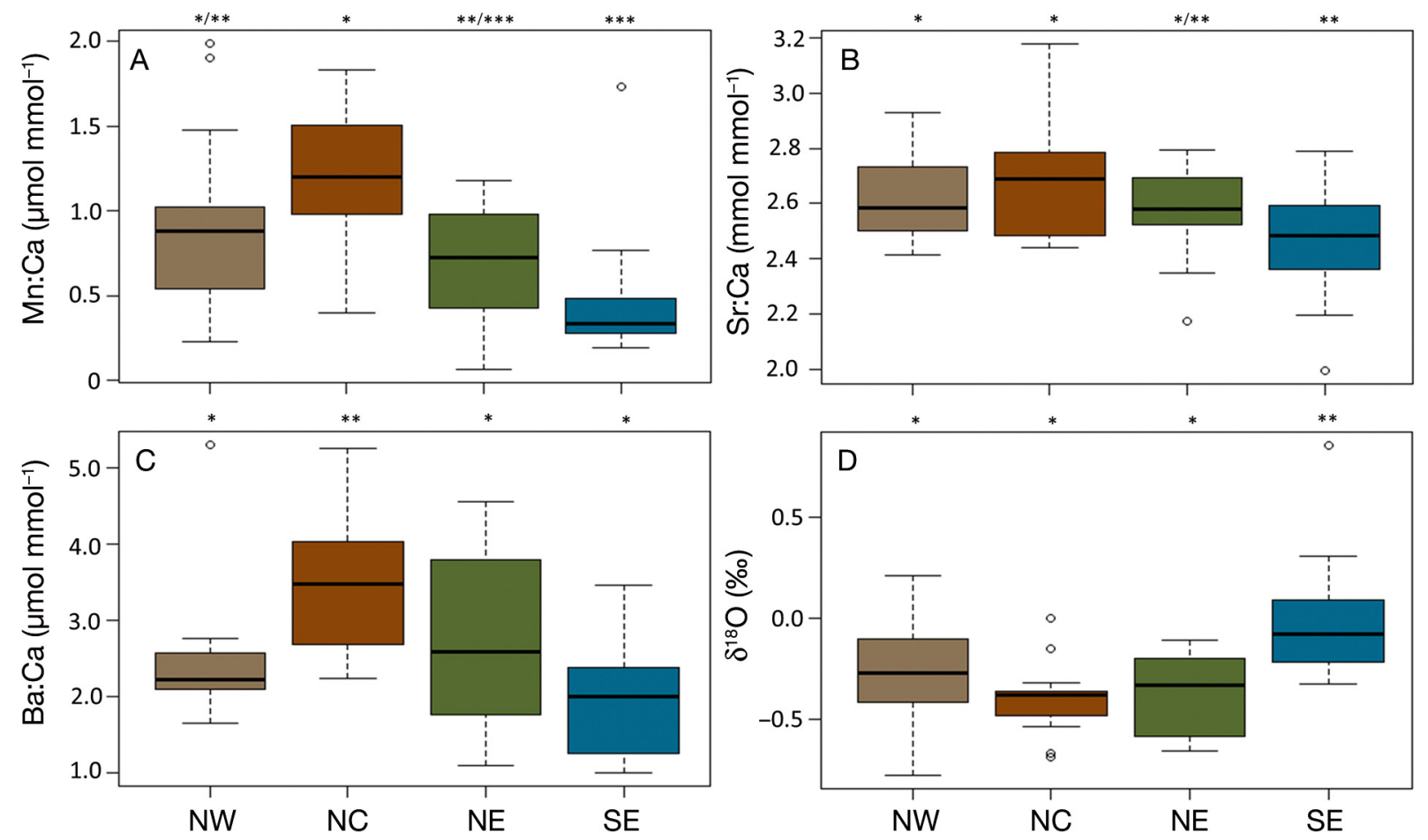

Fig. 5. (A) Mn:Ca, (B) Sr:Ca, and (C) Ba:Ca ratios, and (D) $\delta^{18} \mathrm{O}$ lifetime values by Gulf of Mexico 4-region grouping for the Warsaw grouper stable isotope sample subset $(n=61)$. Other details as in Fig. 3 


\section{DISCUSSION}

Distinct chemical signatures (trace elements and stable isotopes) and high overall classification success ( $85 \%$ or above) to specific geographic regions indicate that the Warsaw grouper population in the GoM likely consists of multiple stock components (Kalish 1989, Ashford et al. 2012, Tanner et al. 2016), with contingents or sub-populations emerging in the NW/NC/NE GoM and the SE GoM. Thus, the singlestock framework currently used to manage the population may not accurately represent the actual population structure of Warsaw grouper in the GoM, which compromises the management of the stock. For example, individual stocks (local populations) should be managed independently for a metapopulation based on stock-specific demographics and exploitation rates (Begg et al. 1999, Pita et al. 2016). Under the single stock framework, exploitation rates for more vulnerable stocks in a metapopulation may exceed sustainable levels under the false assumption of connectivity and replenishment by other segments of the population (Ying et al. 2011). For a species with a periodic life history strategy like the Warsaw grouper, overexploitation can lead to truncation of the population age structure, thereby decreasing the reproductive potential in years when environmental conditions would otherwise lead to a successful yearclass, potentially resulting in local extirpation (Longhurst 2002, Winemiller 2005, Secor et al. 2015).

For Warsaw grouper in the GoM, region-specific differences in otolith chemistry along multiple growth zones suggests that connectivity across regions is lower than currently expected. Patterns in chemical signatures between the NW/NC/NE and SE regions for all 3 life history stages assessed (otolith $_{\text {core, }}$ otolith $_{\text {edge, }}$ and otolith lifetime $_{\text {) were similar, }}$ suggesting that individuals likely remained within specific regions from early life to adult periods. In fact, back-calculated birth years for Warsaw grouper collected in the NW/NC/NE ranged from 2004-2012; nevertheless, region-specific classification success

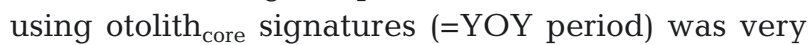
high $(98 \%)$. Therefore, our findings imply that regional differences in otolith chemistry, as influenced by water chemistry, at the geographic scale investigated remain distinct over time and lend credence to the premise that movement or mixing of individuals between these 2 regions is negligible for juvenile and adult stages of Warsaw grouper (Secor 2010). Moreover, region-specific differences were generally consistent between the 2 regions for both YOY/juvenile (otolith core$_{\text {) }}$ and sub-adult/adult

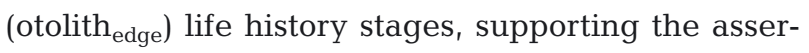
tion that regional contingents or sub-populations may exist for Warsaw grouper in the GoM (Ashford et al. 2005, Rooker \& Secor 2019).

Classification success for Warsaw grouper from the NW and NE in the 4-region grouping using otolith $_{\text {core, }}$ otolith edge, $_{\text {, and otolith }}$ lifetime signatures was distinctly lower than the NC and SE regions. While our inability to effectively classify individuals to these 2 regions using otolith lifetime $_{\text {signatures could be }}$ a result of otolith chemistries reflecting individual residency in a combination of chemically distinct regions (e.g. NC and SE) (Campana 1999), and therefore stock mixing, otolith $\mathrm{core}_{\text {and }}$ otolith $\mathrm{edge}_{\text {analyses }}$ suggest that low success in these 2 regions is a result of intermediate physicochemical conditions. Classification success for the NW and NC regions was low for both otolith core $_{\text {and otolith }}$ edge samples demonstrating that these signatures integrated both the juvenile (YOY) and adult periods, and consequently are not a result of movement through chemically distinct regions over a large geographic range. On the other hand, it seems reasonable to assume that if regional ambient water exhibited intermediate physicochemical characteristics, the integration of the signature in both long-term (lifetime) and shortterm (core/edge) deposition periods would be expected, especially in regions with temporally stable water chemistries.

The 4 analytes $\left(\mathrm{Mn}, \mathrm{Sr}, \mathrm{Ba}, \delta^{18} \mathrm{O}\right)$ in the otoliths of Warsaw grouper that varied regionally showed a common spatial pattern across the GoM, with pronounced differences between the NC and SE regions, and values in the NE and NW regions generally intermediate to the NC and SE. Differences between the NC and SE region are likely a function of 2 mesoscale features that influence the ambient seawater chemistry in each region; the low salinity, nutrient rich Mississippi-Atchafalaya River System (MARS) in the NC and the relatively high salinity, oligotrophic Loop Current (LC) in the SE (Oey et al. 2005, Matli et al. 2018). In addition, the otolith chemistry of Warsaw grouper from the NW region was most similar to the NC region, which is not surprising because inflow from the MARS is known to affect the water chemistry of the NW GoM (Rabalais et al. 2002, Morey et al. 2003a,b). Although the MARS discharge predominantly flows westward, influencing physicochemical properties of the NW GoM (Rabalais et al. 1991, Oey et al. 2005, Matli et al. 2018), reverse flow occurs during the summer months (Morey et al. 2003a,b). Thus, while MARS influence is well known along the Louisiana-Texas coastal 
shelf (NW region), it also likely alters the seawater chemistry in the NE GoM (Walker et al. 2005) and subsequently influences chemical signatures in the otoliths of Warsaw grouper collected in this region.

The MARS influence is apparent when comparing individual chemical markers in the otoliths of Warsaw grouper, and regional patterns were typically retained in all 3 life history stages (core, edge, lifetime). While $\mathrm{Mn}: \mathrm{Ca}$ and $\mathrm{Sr}: \mathrm{Ca}$ ratios would be conservative in intermediate waters of the GoM if salinity was the predominant driver of variability (Sturrock et al. 2012), both elements were higher in the otoliths of Warsaw grouper from regions closest to the MARS inflow point (particularly the NC GoM). Element:Ca ratios for $\mathrm{Mn}, \mathrm{Sr}$, and $\mathrm{Ba}$ have been shown to increase in the otolith deposition of fish collected in nutrient-rich waters (Böhlke \& Horan 2000, Martin et al. 2004, Martin \& Thorrold 2005, Stanley et al. 2015), a characteristic of the MARS inflow, an inflow that has been shown to affect outer shelf waters in the NW region and is expected to influence those in the NE (Rabalais et al. 1991, Morey et al. 2003a,b). Furthermore, these relative patterns were exhibited for both core and edge life history stages even while absolute values changed, suggesting these changes resulted from either an ontogenetic depth shift to waters with less MARS influence or a shift in physiological regulation (Campana 1999, Ruttenberg et al. 2005), but not likely from migration to another region. No direct measurements of water chemistry were made, so it is not possible to reconcile causal mechanisms or the importance of additional factors (e.g. diet, depth shift).

Spatial variability of water chemistry in the Atlantic Ocean is well known, and its influence on otolith chemistry has been documented (Rooker et al. 2008, Wells et al. 2010, Tanner et al. 2016). Relatively few studies, however, have applied otolith chemistry to examine spatial dynamics and other aspects of the ecology of deepwater fishes (Edmonds et al. 1991, Thresher et al. 1994, Kalish et al. 1996), with the most recent applications on this group performed in the Southern Ocean (Ashford et al. 2005, 2012, Zhu et al. 2018). In our study, region-specific differences in otolith $_{\text {core, }}$ otolith edge, $_{\text {and otolith }}$ lifetime signatures of Warsaw grouper from the GoM were detected and indicated that natural markers could be used to correctly classify individuals to certain regions. The most striking difference in otolith chemistry was observed between Warsaw groupers from the NC and SE regions, with physicochemical conditions in the former region heavily influenced by the MARS (Oey et al. 2005, Matli et al. 2018). In contrast, the SE region was the farthest removed from MARS, and the otolith chemistry of Warsaw groupers from this region was distinct, indicating a lack of connectivity between groupers in the NC and SE regions. In addition, otolith $_{\text {core }}$ signatures (YOY or nursery period) were region-specific even though our samples comprised birth years that spanned nearly a decade. Therefore, the spatial variation in the otolith chemistry of Warsaw grouper is sufficient to overcome any temporal shifts in physicochemical conditions within regions. While ontogenetic shifts in migration are possible, little variation in chemical structure of otolith ${ }_{\text {core }}$ and otolith $_{\text {edge }}$ regions suggest limited juvenile/sub-adult inter-regional movements. Our results indicate that assessing chemical signatures from multiple life history stages of an otolith has the potential to increase stock structure resolution for meta-populations whose contingents are spread between geographic areas with relatively homogeneous physicochemical conditions, a common characteristic in individual deepwater masses. Because juvenile/sub-adult Warsaw grouper are a major component of both the commercial and recreational deepwater fisheries and experience high release mortality rates, a multi-stock or metapopulation framework may be needed to improve future assessments and rebuilding plans for this species in the GoM.

Acknowledgements. We acknowledge all members of the Fisheries Ecology Lab (TAMUG) who assisted in the development and sample preparation for this study. We also thank Aline Rocha Franca and Daniel Lippi (UFPE) for assistance with data analysis. Lastly, we thank Dr. David Dettman and others at the University of Arizona Environmental Isotope Laboratory for otolith carbonate stable isotope $\left(\delta^{18} \mathrm{O}\right.$ and $\left.\delta^{13} \mathrm{C}\right)$ analysis. This project was funded through a grant from NOAA Fisheries (Marine Fisheries Initiative Project Award NA16NMF433016). The scientific results and conclusions, as well as any views or opinions expressed herein, are those of the authors and do not necessarily reflect those of NOAA or the Department of Commerce.

\section{LITERATURE CITED}

Aguilar-Perera A, Padovani-Ferreira B, Bertoncini AA (2018) Hyporthodus nigritus. The IUCN Red List of Threatened Species. e.T7860A46909320

Ashford JR, Jones CM, Hofmann E, Everson I, Moreno C, Duhamel G, Williams R (2005) Can otolith elemental signatures record capture site of Patagonian toothfish (Dissostichus eleginoides), a fully marine fish in the Southern Ocean? Can J Fish Aquat Sci 62:2832-2840

Ashford JR, Dinniman M, Brooks C, Andrews AH and others (2012) Does large-scale ocean circulation structure life history connectivity in Antarctic toothfish (Dissostichus mawsoni)? Can J Fish Aquat Sci 69:1903-1919

Böhlke JK, Horan M (2000) Strontium isotope geochemistry 
of groundwaters and streams affected by agriculture, Locust Grove, MD. Appl Geochem 15:599-609

Begg GA, Friedland KD, Pearce JB (1999) Stock identification and its role in stock assessment and fisheries management: an overview. Fish Res 43:1-8

Beltrán DM, Schizas NV, Appeldoorn RS, Prada C (2017) Effective dispersal of Caribbean reef fish is smaller than current spacing among marine protected areas. Sci Rep 7:4689

Bender MG, Floeter SR, Hanazaki N (2013) Do traditional fishers recognize reef fish species declines? Shifting environmental baselines in eastern Brazil. Fish Manag Ecol 20:58-67

* Campana SE (1999) Chemistry and composition of fish otoliths: pathways, mechanisms and applications. Mar Ecol Prog Ser 188:263-297

Coleman FC, Koenig CC, Huntsman FR, Musick JA and others (2000) Long-lived reef fishes: the grouper-snapper complex. Fisheries 25:14-21

Cowen RK, Gawarkiewicz G, Pineda J, Thorrold SR, Werner FE (2007) Population connectivity in marine systems: an overview. Oceanography 20:14-21

Edmonds JS, Caputi N, Morita M (1991) Stock discrimination by trace-element analysis of otoliths of orange roughy (Hoplostethus atlanticus), a deep-water marine teleost. Aust J Mar Freshwater Res 42:383-389

Elsdon RS, Wells BK, Campana SE, Gillanders BM and others (2008) Otolith chemistry to describe movements and life-history parameters of fishes-hypotheses, assumptions, limitations and inferences. Oceanogr Mar Biol Annu Rev 46:297-330

Farmer NA, Karnauskas M (2013) Spatial distribution and conservation of speckled hind and Warsaw grouper in the Atlantic Ocean off the southeastern U.S. PLOS ONE 8:e78682

Gerber BD, Kendall WL (2016) Considering transient population dynamics in the conservation of slow life-history species: an application to the sandhill crane. Biol Conserv 200:228-239

Gillanders BM (2005) Using elemental chemistry of fish otoliths to determine connectivity between estuarine and coastal habitats. Estuar Coast Shelf Sci 64:47-57

GMFMC (Gulf of Mexico Fishery Management Council) (2018) Grouper-tilefish individual fishing quota program 5-year review. http://gulfcouncil.org/wp-content/uploads/ B-9a-Grouper-Tilefish-Review-March-2018.pdf

Kalish JM (1989) Otolith microchemistry: validation of the effects of physiology, age and environment on otolith composition. J Exp Mar Biol Ecol 132:151-178

Kalish JM, Livingston ME, Schofield KA (1996) Trace elements in the otoliths of New Zealand blue grenadier (Macruronus novaezelandiae) as an aid to stock discrimination. Mar Freshw Res 47:537-542

Kitchens LL, Rooker JR, Reynal L, Falterman BJ, Saillant E, Murua H (2018) Discriminating among yellowfin tuna Thunnus albacares nursery areas in the Atlantic Ocean using otolith chemistry. Mar Ecol Prog Ser 603:201-213

Koenig CC, Coleman FC (2013) Protection of grouper and red snapper spawning in shelf-edge marine reserves of the northeastern Gulf of Mexico: demographics, movements, survival, and spillover effects. SEDAR 33-DW02. SEDAR, North Charleston, SC. http://sedarweb.org/ s33dw02-protection-grouper-and-red-snapper-spawningshelf-edge-marine-reserves-northeastern-gulf

Longhurst A (2002) Murphy's law revisited: longevity as a factor in recruitment to fish populations. Fish Res 56: 125-131

Manooch CS III, Mason DL (1987) Age and growth of the Warsaw grouper and black grouper from the southeast region of the United States. Northeast Gulf Sci 9:65-75

* Martin GB, Thorrold SR (2005) Temperature and salinity effects on magnesium, manganese, and barium incorporation in otoliths of larval and early juvenile spot Leiostomus xanthurus. Mar Ecol Prog Ser 293:223-232

*Martin GB, Thorrold SR, Jones CM (2004) Temperature and salinity effects on strontium incorporation in otoliths of larval spot (Leiostomus xanthurus). Can J Fish Aquat Sci 61:34-42

Matli VRR, Fang S, Guinness J, Rabalais NN, Craig JK, Obenour DR (2018) Space-time geostatistical assessment of hypoxia in the northern Gulf of Mexico. Environ Sci Technol 52:12484-12493

Mejía-Ladino LM, Betancur R, Acero A, Grijalba M (2003) Presencia de Epinephelus nigritus (Pisces: Serranidae) en el Caribe Colombiano, incluyendo una clave para las especies de Epinephelus en el área. Bol Ecotropica Ecosistemas Trop 37:31-39

* Merten W, Appeldoorn R, Hammond D (2016) Movement dynamics of dolphinfish (Coryphaena hippurus) in the northeastern Caribbean Sea: evidence of seasonal reentry into domestic and international fisheries throughout the western central Atlantic. Fish Res 175:24-34

*Morey SL, Martin PJ, O'Brien JJ, Wallcraft AA, ZavalaHidalgo J (2003a) Export pathways for river discharged fresh water in the northern Gulf of Mexico. J Geophys Res 108:3303

*Morey SL, Schroeder WW, O'Brien JJ, Zavala-Hidalgo J (2003b) The annual cycle of riverine influence in the eastern Gulf of Mexico. Geophys Res Lett 30:1867

* Oey LY, Ezer T, Lee HC (2005) Loop current, rings and related circulation in the Gulf of Mexico: a review of numerical models and future challenges. In: Sturges W, Lugo-Fernandez A (eds) Circulation in the Gulf of Mexico: observations and models, Vol 161. American Geophysical Union, Washington, DC, p 31-56

Parker RO, Mays RW (1998) Southeastern U.S. deepwater reef fish assemblages, habitat characteristics, catches, and life history summaries. NOAA NMFS Tech Rep 138

* Pita A, Casey J, Hawkins SJ, Villareal MR and others (2016) Conceptual and practical advances in fish stock delineation. Fish Res 173:185-193

Policansky D, Magnuson JJ (1998) Genetics, metapopulations, and ecosystem management of fisheries. Ecol Appl 8(Suppl):S119-S123

*Quetglas A, Rueda L, Alvarez-Berastegui D, Guijarro B, Massuti E (2016) Contrasting responses to harvesting and environmental drivers of fast and slow life history species. PLOS ONE 11:e0148770

Rabalais NN, Turner RE, Wiseman WJ, Boesch DF (1991) A brief summary of hypoxia on the northern Gulf of Mexico continental shelf: 1985-1958. Geol Soc Lond Spec Publ 58:35-47

Rabalais NN, Turner RE, Wiseman WJ (2002) Gulf of Mexico hypoxia, a.k.a. 'The Dead Zone'. Annu Rev Ecol Syst 33: 235-263

Rooker JR, Secor DH (2019) Otolith microchemistry: migration and ecology of Atlantic bluefin tuna. In: Block BA (ed) The future of bluefin tuna: ecology, fisheries management, and conservation. Johns Hopkins University Press, Baltimore, MD, p 45-66 
Rooker JR, Secor DH, De Metrio G, Schloesser R, Block BA, Neilson JD (2008) Natal homing and connectivity in Atlantic bluefin tuna populations. Science 322:742-744

Rooker JR, Stunz GW, Holt SA, Minello TJ (2010) Population connectivity of red drum in the northern Gulf of Mexico. Mar Ecol Prog Ser 407:187-196

Rooker JR, Arrizabalaga H, Fraile I, Secor DH and others (2014) Crossing the line: migratory and homing behaviors of Atlantic bluefin tuna. Mar Ecol Prog Ser 504: 265-276

Rooker JR, Dance MA, Wells RJD, Ajemian MJ and others (2019) Population connectivity of pelagic megafauna in the Cuba-Mexico-United States triangle. Sci Rep 9:1663

Ruttenberg BI, Hamilton SL, Hickford MJH, Paradis GL and others (2005) Elevated levels of trace elements in cores of otoliths and their potential for use as natural tags. Mar Ecol Prog Ser 297:273-281

Ruzzante DE, Taggart CT, Lang S, Cook D (2000) Mixed stock analysis of Atlantic cod near the Gulf of St. Lawrence based on microsatellite DNA. Ecol Appl 10: 1090-1109

Sanchez PJ, Pinksy J, Rooker JR (2019) Bomb radiocarbon age validation of Warsaw grouper and snowy grouper. Fisheries 44:524-533

Secor DH (2010) Is otolith science transformative? New views on fish migration. Environ Biol Fishes 89:209-220

Secor DH, Rooker JR, Gahagan BI, Siskey MR, Wingate RW (2015) Depressed resilience of bluefin tuna in the western Atlantic and age truncation. Conserv Biol 29:400-408

Shertzer KW, Bacheler NM, Kellison GT, Fieberg J, Wiggers RK (2018) Release mortality of endangered Warsaw grouper Hyporthodus nigritus: a state-space model applied to capture-recapture data. Endang Species Res 35:15-22

Shurin JB, Borer T, Seabloom EW, Anderson K and others (2002) A cross-ecosystem comparison of the strength of trophic cascades. Ecol Lett 5:785-791

Smith CL (1971) A revision of the American groupers: Epinephelus and allied genera. Bull Am Mus Nat Hist 146:67-242

Stanley RRE, Bradbury IR, DiBacco C, Snelgrove PVR, Thorrold SR, Killen SS (2015) Environmentally mediated trends in otolith composition of juvenile Atlantic cod (Gadus morhua). ICES J Mar Sci 72:2350-2363

Sturrock AM, Trueman CN, Darnaude AM, Hunter E (2012) Can otolith elemental chemistry retrospectively track migrations in fully marine fishes? J Fish Biol 81:766-795
Tanner SE, Reis-Santos P, Cabral HN (2016) Otolith chemistry in stock delineation: a brief overview, current challenges and future prospects. Fish Res 173:206-213

* Thorrold SR, Jones CM, Swart PK, Targett TE (1998) Accurate classification of juvenile weakfish Cynoscion regalis to estuarine nursery areas based on chemical signatures in otoliths. Mar Ecol Prog Ser 173:253-265

* Thorrold SR, Latkoczy C, Swart PK, Jones CM (2001) Natal homing in a marine fish metapopulation. Science 291: 297-299

Thresher RE (1999) Elemental composition of otoliths as a stock delineator in fishes. Fish Res 43:165-204

Thresher RE, Proctor CH, Gunn JS, Harrowfield IR (1994) An evaluation of electron-probe microanalysis of otoliths for stock delineation and identification of nursery areas in a southern temperate groundfish, Nemadactylus macropterus (Cheilodactylidae). Fish Bull 92:817-840

Walker ND, Wiseman WJ, Rouse LJ, Babin A (2005) Effects of river discharge, wind stress, and slope eddies on circulation and the satellite-observed structure of the Mississippi River plume. J Coast Res 216:1228-1244

*Wells RJD, Rooker JR, Pince ED (2010) Regional variation in the otolith chemistry of blue marlin (Makaira nigricans) and white marlin (Tetrapturus albidus) from the North Atlantic Ocean. Fish Res 106:430-435

WWells RJD, Kinney MJ, Kohin S, Dewar H, Rooker JR, Snodgrass OE (2015) Natural tracers reveal population structure of albacore (Thunnus alalonga) in the eastern North Pacific. ICES J Mar Sci 72:2118-2127

*Winemiller KO (2005) Life history strategies, population regulation, and implications for fisheries management. Can J Fish Aquat Sci 62:872-885

Winemiller KO, Rose KA (1992) Patterns of life-history diversification in North American fishes: implications for population regulation. Can J Fish Aquat Sci 49:2196-2218

* Ying Y, Chen Y, Longshan L, Tianzian G (2011) Risks of ignoring fish population structure in fisheries management. Can J Fish Aquat Sci 68:2101-2120

* Zapp Sluis M, Barnett BK, Patterson WF III, Cowan JH Jr, Shiller AM (2012) Discrimination of juvenile red snapper otolith chemical signatures from Gulf of Mexico nursery regions. Mar Coast Fish 4:587-598

* Zhu G, Duan M, Ashford JR, Wei L, Zhou M, Bestley S (2018) Otolith nucleus distinguishes Electrona antarctica in the westward-flowing Antarctic slope current and eastward-flowing Antarctic circumpolar current off east Antarctica. Mar Environ Res 142:7-20 


\section{Appendix}

Table A1. Mean (SD) values for element:Ca ratios and stable isotopes for all regions in the 4-region Gulf of Mexico grouping scheme for the core, edge, and lifetime signatures in Warsaw grouper otoliths. All lifetime values were analyzed on a sample subset $(n=61)$ used to quantify stable isotopes. NW: Northwest; NC: Northcentral; NE: Northeast; SE: Southeast

\begin{tabular}{|c|c|c|c|c|c|}
\hline & Element & NW & $\mathrm{NC}$ & NE & $\mathrm{SE}$ \\
\hline \multirow[t]{8}{*}{ Core $(\%)$} & ${ }^{7} \mathrm{Li}: \mathrm{Ca}$ & $4.98(0.80)$ & $4.86(1.43)$ & $5.39(0.88)$ & 5.12 (1.16) \\
\hline & ${ }^{24} \mathrm{Mg}: \mathrm{Ca}$ & $140.8(24.7)$ & $150.9(23.2)$ & $144.2(30.5)$ & $136.4(21.1)$ \\
\hline & ${ }^{55} \mathrm{Mn}: \mathrm{Ca}$ & $2.55(0.91)$ & 3.09 (1.32) & $2.26(1.03)$ & $1.12(0.38)$ \\
\hline & ${ }^{59} \mathrm{Co}: \mathrm{Ca}$ & $0.24(0.24)$ & $0.25(0.17)$ & $0.14(0.14)$ & $0.23(0.19)$ \\
\hline & ${ }^{65} \mathrm{Cu}: \mathrm{Ca}$ & $1.06(0.64)$ & $0.68(0.54)$ & $0.92(0.67)$ & $0.60(0.67)$ \\
\hline & ${ }^{66} \mathrm{Zn}: \mathrm{Ca}$ & $1.29(0.61)$ & $1.15(0.55)$ & $1.28(1.06)$ & $0.88(0.41)$ \\
\hline & ${ }^{88} \mathrm{Sr}: \mathrm{Ca}$ & $2451(271)$ & 2715 (304) & $2579(390)$ & $2527(274)$ \\
\hline & ${ }^{137} \mathrm{Ba}: \mathrm{Ca}$ & 4.19 (2.09) & $5.03(2.04)$ & $5.07(3.60)$ & $3.45(1.94)$ \\
\hline \multirow[t]{8}{*}{ Edge (\%o) } & ${ }^{7} \mathrm{Li}: \mathrm{Ca}$ & $1.91(2.10)$ & $2.13(2.35)$ & $1.60(1.03)$ & $2.68(3.02)$ \\
\hline & ${ }^{24} \mathrm{Mg}: \mathrm{Ca}$ & $46.8(10.1)$ & $44.5(10.4)$ & $52.2(12.3)$ & 46.34 (8.49) \\
\hline & ${ }^{55} \mathrm{Mn}: \mathrm{Ca}$ & $0.11(0.28)$ & $0.21(0.14)$ & $0.19(0.20)$ & $0.20(0.23)$ \\
\hline & ${ }^{59} \mathrm{Co}: \mathrm{Ca}$ & $0.18(0.20)$ & $0.25(0.20)$ & $0.09(0.20)$ & $0.16(0.19)$ \\
\hline & ${ }^{65} \mathrm{Cu}: \mathrm{Ca}$ & $0.05(0.33)$ & $0.16(0.35)$ & $0.31(0.39)$ & $0.32(0.38)$ \\
\hline & ${ }^{66} \mathrm{Zn}: \mathrm{Ca}$ & $0.52(0.24)$ & $0.51(0.38)$ & $0.43(0.29)$ & $0.44(0.38)$ \\
\hline & ${ }^{88} \mathrm{Sr}: \mathrm{Ca}$ & 2944 (538) & 3045 (373) & 2731 (409) & 2637 (345) \\
\hline & ${ }^{137} \mathrm{Ba}: \mathrm{Ca}$ & $1.49(0.61)$ & $1.89(0.95)$ & $1.36(0.48)$ & $0.85(0.18)$ \\
\hline \multirow[t]{10}{*}{ Lifetime (\%o) } & ${ }^{7} \mathrm{Li}: \mathrm{Ca}$ & $3.11(1.41)$ & $3.09(1.51)$ & $3.09(0.31)$ & 3.71 (1.36) \\
\hline & ${ }^{24} \mathrm{Mg}: \mathrm{Ca}$ & $83.5(15.7)$ & $81.5(10.5)$ & $91.8(22.3)$ & $79.2(12.7)$ \\
\hline & ${ }^{55} \mathrm{Mn}: \mathrm{Ca}$ & $0.88(0.49)$ & $1.09(0.49)$ & $0.68(0.36)$ & $0.48(0.35)$ \\
\hline & ${ }^{59} \mathrm{Co}: \mathrm{Ca}$ & $0.27(0.19)$ & $0.22(0.16)$ & $0.12(0.14)$ & $0.21(0.15)$ \\
\hline & ${ }^{65} \mathrm{Cu}: \mathrm{Ca}$ & $0.50(0.49)$ & $0.35(0.35)$ & $0.33(0.37)$ & $0.39(0.56)$ \\
\hline & ${ }^{66} \mathrm{Zn}: \mathrm{Ca}$ & $0.69(0.55)$ & $0.53(0.35)$ & $0.45(0.33)$ & $0.53(0.29)$ \\
\hline & ${ }^{88} \mathrm{Sr}: \mathrm{Ca}$ & 2652 (220) & 2773 (206) & 2570 (189) & 2459 (192) \\
\hline & ${ }^{137} \mathrm{Ba}: \mathrm{Ca}$ & $2.57(0.95)$ & $3.23(0.93)$ & $2.74(1.18)$ & $1.95(0.71)$ \\
\hline & $\delta^{13} \mathrm{C}$ & $-3.98(0.33)$ & $-4.15(0.34)$ & $-4.09(0.30)$ & $-4.05(0.61)$ \\
\hline & $\delta^{18} \mathrm{O}$ & $-0.29(0.27)$ & $-0.41(0.16)$ & $-0.39(0.21)$ & $-0.01(0.28)$ \\
\hline
\end{tabular}

Editorial responsibility: Myron Peck, Hamburg, Germany
Submitted: March 4, 2020; Accepted: August 3, 2020 Proofs received from author(s): September 7, 2020 